CLINICAL STUDY

\title{
Expression of adrenomedullin in adipose tissue of lean and obese women
}

\author{
O Paulmyer-Lacroix ${ }^{1,2}$, R Desbriere ${ }^{3}$, M Poggi ${ }^{1,2}$, V Achard $^{1,2}$, M-C Alessi ${ }^{1,2}$, F Boudouresque $^{2,4}$ L'H Ouafik $^{2,4}$, \\ V Vuaroqueaux ${ }^{5}$, M Labuhn $^{5}$, A Dutour ${ }^{1,2}$ and , M Grino ${ }^{1,2}$ \\ ${ }^{1}$ Inserm UMR 626, UFR de Médecine secteur Timone, 27 Bd Jean Moulin, 13385 Marseille cedex 5, France, ${ }^{2}$ Faculty of Medicine, Université de la \\ Méditerranée, Aix-Marseille II, France, ${ }^{3}$ Department of Gynecology, Assistance Publique - Hôpitaux de Marseille, CHU Nord, France, ${ }^{4}$ Inserm \\ EMI 0359, Marseille, France and ${ }^{5}$ OncoScore AG, Riehen, Switzerland \\ (Correspondence should be addressed to O Paulmyer-Lacroix; Email: odile.lacroix-paulmyer@mail.ap-hm.fr)
}

\begin{abstract}
Objective: Adrenomedullin (AM), a potent vasodilatator and antioxidative peptide, was shown recently to be expressed by adipose tissue. The aim of our study was to investigate the precise localization of AM within human adipose tissue, and to examine AM regulation in obesity.

Design: Subcutaneous (SC) and omental (OM) adipose tissues from 9 lean and 13 obese women were profiled for AM expression changes. Preadipocytes from human adipose tissue were isolated and differentiated under defined adipogenic conditions.

Methods: AM expression was analyzed by immunohistochemistry, in situ hybridization and quantitative RT-PCR.

Results: A strong AM expression was observed in vessel walls, stromal cell clusters and isolated stromal cells, some of them being CD 68 positive, whereas mature adipocytes were not labeled. Calcitonin receptor-like receptor and receptor activity-modifying proteins (RAMP) 2 and RAMP 3 were expressed in vessel walls. In vitro, preadipocytes of early differentiation stages spontaneously secreted AM. No difference in AM localization was found between SC and OM adipose tissue. AM levels in SC tissue did not differ between lean and obese subjects. By contrast, AM levels in OM tissue were significantly higher in obese as compared with lean women. Moreover, we found a positive relationship between OM $\mathrm{AM}$ and tumor necrosis factor $\alpha$ mRNA levels and AM-immunoreactive area in OM tissue followed the features of the metabolic syndrome.

Conclusion: Stromal cells from human adipose tissue, including macrophages, produce AM. Its synthesis increased in the OM territory during obesity and paralleled the features of the metabolic syndrome. Therefore, AM should be considered as a new member of the adipokine family.
\end{abstract}

European Journal of Endocrinology 155 177-185

\section{Introduction}

Adrenomedullin (AM) is a 52-amino acid peptide initially isolated from a human pheochromocytoma (1). It displays potent vasodilating and antioxidative effects, and has angiogenic and growth factor properties (2). AM acts through seven-transmembrane domain $G$ protein-coupled receptors which associate the calcitonin receptor-like receptor (CRLR) and modulating proteins, namely receptor activity-modifying proteins (RAMP) 2 and RAMP 3 (3). AM is produced by different tissues and cell types in humans, such as adrenal gland (1), heart (4), vascular endothelial cells (5), and vascular smooth muscle cells (6). However, the precise origins of circulating AM are not clear. Comparisons of AM concentrations in arterial and venous blood samples obtained from various vascular beds did not allow any significant site of production of AM to be elucidated (7). Besides the adrenal gland and the vasculature, which are thought to be the major sites of AM synthesis (5), the heart could be a source of circulating AM under particular pathological conditions, e.g. left ventricular dysfunction, cardiac hypertropy or heart failure $(4,8)$. Interestingly, plasma AM concentrations correlate with body mass index (BMI) (9, 10). Circulating AM is elevated in overweight patients with essential hypertension and is decreased by a hypocaloric diet (11). Although the abovementioned diet-induced changes in circulating AM levels could be subsequent to the improvement in blood pressure, this also suggests that adipose tissue may be a source of plasma AM. However, the production of AM by adipose tissue is not entirely documented. Several studies demonstrated that 3T3-L1 and 3T3F442 A cells (murine established cell lines) synthesize AM (12-14) and that rat adipose tissue contains AM mRNA (13). Adipose tissue obtained from rats fed a high fat diet expresses greater amounts of AM than that 
obtained from rats fed a normal diet (13). Recent studies showed, using real time (RT)-PCR, that AM mRNA is present in human adipose tissue collected during surgery $(15,16)$, and that AM peptide is produced by isolated human adipocytes (14), exposed to an inflammatory environment (16). Identically, human mesenchymal stem cell-derived adipocytes express AM in response to proinflammatory cytokines (16).

However, the histological localization of AM within adipose tissue, which represents a highly heterogeneous tissue with functionally specialized compartments, has not been undertaken so far and the influence of obesity on AM biosynthesis has not yet been documented. We thus investigated AM expression in human adipose tissue obtained from both lean and obese women showing uncomplicated obesity. In addition, we searched for in vitro AM secretion from human preadipocytes undergoing in vitro differentiation.

\section{Subjects and methods}

The study was conducted in accordance with the guidelines proposed in the Declaration of Helsinki and was approved by the local hospital and university ethics committee. A total of 22 normally cycling women, between 23 and 50 years of age, with no endocrine, cardiovascular, hepatic, renal, or inflammatory disease, were investigated: 9 normal weight $\left(\mathrm{BMI}<25 \mathrm{~kg} / \mathrm{m}^{2}\right)$, and 13 obese women $\left(\mathrm{BMI}>30 \mathrm{~kg} / \mathrm{m}^{2}\right)$. With respect to the menstrual cycle, most of the patients were in the follicular phase ( 6 and 11 in normal weight and obese women respectively). All patients showed little or no recent change in body weight (i.e. less than $2 \%$ variation). None of the patients were treated for diabetes or high blood pressure. Informed consent was obtained from patients. Subcutaneous (SC) and omental (OM) abdominal adipose tissues were simultaneously obtained at the beginning of surgery for non-infectious, non-endocrine or non-tumoral gynecological disease. One part of the tissue was fixed in 4\% paraformaldehyde, and paraffin embedded. Five micrometer-thick sections were then cut, mounted onto glass slides (SuperFrost/Plus, 0. Kindler GmbH, Freiburg, Germany) and used for immunohistochemistry and in situ hybridization. The other part of the adipose tissue $(200 \mathrm{mg})$ was immediately frozen on dry ice and stored at $-70{ }^{\circ} \mathrm{C}$ until used for quantitative RT-PCR.

\section{Analytical measurements}

\section{Biometric measurement}

After blood pressure evaluation, height and weight were measured using the same scales for all patients (SECA, Vogel \& Halke, Hamburg, Germany) to calculate BMI $\left(\mathrm{kg} / \mathrm{m}^{2}\right)$. Waist and hip circumferences were measured. Percentage of body fat was assessed by impedancemetry.

\section{Blood metabolic measurement}

Fasting glycemia, total cholesterol, high density lipoprotein (HDL) cholesterol, low density lipoprotein (LDL) cholesterol, triglycerides and uric acid were measured using automatized enzymatic assays (Vitros, OrthoClinical Diagnostics, Inc, Rochester, NY, USA). Serum fasting insulin was measured using an immunoradiometric assay (Sanofi-Pasteur Diagnostics; Marnes-laCoquette, France). The estimate of insulin sensitivity by homeostasis model assessment (HOMA) index was calculated as follows: serum fasting insulin $(\mathrm{mIU} / \mathrm{l}) \times$ fasting glycemia (mmol/l)/22.5 (17). Circulating plasminogen activator inhibitor type 1 (PAI-1), a prothrombotic and acute-phase react protein, was measured using an in-house ELISA (18).

\section{Immunohistochemistry}

Polyclonal antibody to AM, CRLR, RAMP 2 and 3 were raised in female New Zealand rabbits after repeated immunizations with the peptides (Bachem, Voisins Le Bretonneux, France) corresponding to amino acids $1-52,89-119,59-81$, and 34-55 of the human AM, CRLR, RAMP 2 and 3 respectively, emulsified with complete Freund's adjuvant. The specificity of the antisera has been described previously $(19,20)$.

All procedures were performed at room temperature. After dewaxing and rehydration, slides were treated with $1 \%$ hydrogen peroxide in PBS and washed in PBS. Slides were subsequently incubated for $2 \mathrm{~h}$ in $3 \%$ normal sheep serum (NSS) in PBS, and overnight with the AM, CRLR, RAMP 2 or 3 antisera (diluted in PBS, $1 \%$ NSS $1 / 1000,1 / 3000,1 / 1500$ and $1 / 2000$ respectively). After washing, slides were incubated for $2 \mathrm{~h}$ with the secondary antibody (biotinylated antirabbit IgG, Vector Laboratories, distributed by AbCys, Paris, France, diluted 1/200 in PBS, 1\% NSS). After washing in PBS, slides were incubated for $2 \mathrm{~h}$ with the avidin-biotin-peroxidase complex (Vectastain ABC System, Vector Laboratories, distributed by Clinisciences, Montrouge, France) and subsequently developed using 3,3'-diaminobenzidine and counterstained with Mayer's hematoxylin. Control sections included omission of primary antibodies. Brightfield images were captured with a color CCD camera (Coolsnap, Roper Scientific, Every, France) attached to a Leica microscope (Rueil-Malmaison, France) and digitized. Tissue AM peptide was quantified by measuring the AM-immunoreactive areas (AM-IR) using the Image software (21). Eight randomly chosen fields $\left(0.7 \mathrm{~mm}^{2}\right)$ per section were analyzed. To secure against a confounding effect of difference in size of adipocytes, we used two ways of surface measurement. For stromal cell clusters, the stained stromal area was divided by the 
total surface of the cluster (percentage of labeled stromal area). For stromal tissue close to adipocytes, the stained stromal area was divided by the number of adipocytes counted in the examined field (labeled stromal surface/ adipocyte). Antibody against leptin was used as positive control of adipocyte staining and immunohistochemistry was performed as already described (22).

For double labeling for AM and CD 68, background autofluorescence was abolished before the assay by using an in-house-built photobleaching box. Slides were blocked with PBS containing 3\% NSS and subsequently incubated overnight in PBS containing 1\% NSS, the antiAM antiserum and a monoclonal antibody anti-CD 68 (clone 514H12, Serotec, Cergy Saint Christophe, France) diluted $1 / 20$. Slides were subsequently rinsed thrice in PBS, and incubated for $2 \mathrm{~h}$ with fluorescein-conjugated goat anti-rabbit IgG and rhodamine (TRITC)-conjugated goat anti-mouse IgG (Jackson ImmunoResearch, West Grove, PA, USA) both diluted 1/200. Preparations were then observed using a True Confocal Scanner microscope $(40 \times$ magnification) coupled to $4 \mathrm{D}$ software. Controls included omission of primary antibodies.

\section{In situ hybridization}

After dewaxing and rehydration, slides were processed and hybridized as previously described (23). The probe was a $1.2 \mathrm{bp} \mathrm{kb}$ cDNA fragment of the human AM gene (24), subcloned in pPCRScript, linearized with Sal I (antisense probe) or with Not I (sense probe) and labeled with ${ }^{35}$ S-UTP (Perkin-Elmer, Courtaboeuf, France). The specificity of the AM probe has already been described (19). After hybridization and washing, slides were exposed to X-ray films (Biomax MR, Kodak, Le Pontet, France) for 8 days, concomitantly with ${ }^{14} \mathrm{C}$ standards, and subsequently dipped in nuclear emulsion $(1: 1$ in water, KS, Ilford, Saint-Priest, France) and exposed for 5 weeks. After development, sections were counterstained with Solid Red.

Leptin antisense riboprobe was used as previously described as a positive control of adipocyte labeling (22).

\section{Quantitative RT-PCR}

Total RNA was extracted using the RNeasy Lipid Tissue Mini Kit (Qiagen, Courtaboeuf, France) according to the manufacturer's recommendations. All RNA samples were quantified and checked for quality on the Bioanalyzer 2100 using the RNA 6000 Nano LabChipKit (Agilent Technologies, Massy, France) following the manufacturer's recommendations. RNA samples were reverse transcribed using $1 \mu \mathrm{g}$ total RNA in a final volume of $20 \mu \mathrm{l}$. Final concentrations were $10 \mathrm{mM}$ diphenyl-trichloroethane, $1 \mu \mathrm{g}$ hexamer primers, $2 \mathrm{U}$ MMLV reverse transcriptase (Invitrogen, Cergy Pontoise, France), $40 \mathrm{U}$ RNasin (Promega, Charbonnièreles-Bains, France), $0.5 \mathrm{mM}$ of each dNTP (Promega) and $1 \times$ reaction buffer. RNA, random hexamer primers and dNTPs were incubated for $5 \mathrm{~min}$ at $65^{\circ} \mathrm{C}$, cooled for $5 \mathrm{~min}$ at $4{ }^{\circ} \mathrm{C}$ and warmed for $10 \mathrm{~min}$ at $25^{\circ} \mathrm{C}$ before the rest of the reaction mix was added. Reverse transcription was carried out at $37^{\circ} \mathrm{C}$ for $50 \mathrm{~min}$ followed by $5 \mathrm{~min}$ at $42{ }^{\circ} \mathrm{C}$. After the reaction, $180 \mu \mathrm{l} \mathrm{H}_{2} \mathrm{O}$ were added and cDNAs were stored at $-20{ }^{\circ} \mathrm{C}$ until use.

Primers (GeneScan Europe, Freiburg, Germany) were designed using the Primer Express v2.0 software (Applied Biosystems, Forster City, CA, USA). The primers for AM were: forward CCGTCGCCCTGATGTACCT and reverse CCCACTTATTCCACTTCTTTCGAA, for tumor necrosis factor $\alpha(\mathrm{TNF} \alpha)$ : forward CCCAGGGACCTCTCTCTAATCAG and reverse GCTTGAGGGTTTGCTACAACATG, and for ribosomal 18S: forward CTACCACATCCAAGGAAGGCA and reverse TTTTTCGTCACTACCTCCCCG.

PCR was performed in standard conditions $\left(95^{\circ} \mathrm{C}\right.$ for $15 \mathrm{~s}$ followed by $60^{\circ} \mathrm{C}$ for $\left.1 \mathrm{~min}\right)$ in 40 cycles on an ABI Prism 7000 using the $2 \times$ SYBR Green I Master Mix (Applied Biosystems) in a final volume of $25 \mu \mathrm{l}$. Primer concentration was $0.2 \mu \mathrm{M}$ each. After PCR reaction, amplicons were submitted to a temperature ramping, analyzed for their specific melting points.

Relative quantification $(\Delta \mathrm{cT})$ was obtained by normalization against the ribosomal $18 \mathrm{~S}(\Delta \mathrm{cT}=\mathrm{cT}$ target gene - cT 18S) and expressed in arbitrary units $\left(=2^{-(\Delta \mathrm{cT})} \times 10^{11}\right)$.

\section{AM secretion during in vitro preadipocytes differentiation}

All reagents were purchased from Sigma (L'Isle D'Abeau Chesnes, France). Cultures of SC preadipocytes, issued from five subjects among the lean population tissue, undergoing differentiation were prepared as previously described (22). After collagenase digestion and erythrocyte lysis, stromal cells isolated from adipocytes were resuspended in DME/ HAMF12 medium supplemented with $15 \mathrm{mmol} / \mathrm{l}$ $\mathrm{NaH}_{2} \mathrm{CO}_{3}, 33 \mu \mathrm{mol} / \mathrm{l}$ biotin, and $17 \mu \mathrm{mol} / \mathrm{l}$ panthotenate. After cell attachment, the medium was switched to a differentiation mixture that consisted of the same medium enriched $252 \mu \mathrm{mol} / \mathrm{l}$ isobutylmethylxanthine (IBMX), $5 \mathrm{mg} / \mathrm{l}$ insulin, $5 \mathrm{mg} / \mathrm{l}$ transferrin, $5 \mu \mathrm{g} / \mathrm{l}$ selenium, $1 \mu \mathrm{mol} / \mathrm{l}$ dexamethasone, and $1 \mathrm{nmol} / \mathrm{l}$ triiodothyronine. After 2 days of incubation, IBMX was retrieved and medium was then changed every $48 \mathrm{~h}$ for 12 days. Aliquots of medium were centrifuged and the resulting supernatant was immediately frozen at $-20{ }^{\circ} \mathrm{C}$ until assay. AM levels were measured with a specific radioimmunoassay, as previously described (19). Leptin levels were measured using an enzyme immunoassay technique (Quantikine, R\&D Systems, distributed by R\&D Systems Europe, Abingdon, Oxon, UK), and were used as a marker of adipocyte maturation. Results were expressed as percentage of AM or leptin control value measured on the second day of culture, before differentiation. 
Table 1 Subject characteristics. Data are expressed as the mean \pm S.E.M.

\begin{tabular}{|c|c|c|c|}
\hline & Lean & Obese & $P$ \\
\hline$n$ & 9 & 13 & \\
\hline Age $(y r)$ & $42.5 \pm 2.2$ & $37.5 \pm 2.5$ & NS \\
\hline BMI $\left(\mathrm{kg} / \mathrm{m}^{2}\right)$ & $20.7 \pm 0.6$ & $38.7 \pm 1.1$ & ** \\
\hline Waist circumference $(\mathrm{cm})$ & $68.5 \pm 0.8$ & $106.3 \pm 1.7$ & ** \\
\hline Waist/hip ratio & $0.73 \pm 0.01$ & $0.85 \pm 0.03$ & ** \\
\hline Fat mass (\%) & $23.8 \pm 1.3$ & $44.1 \pm 1.0$ & ** \\
\hline $\begin{array}{l}\text { Systolic blood pressure } \\
(\mathrm{mmHg})\end{array}$ & $106 \pm 20$ & $121 \pm 27$ & * \\
\hline $\begin{array}{l}\text { Diastolic blood pressure } \\
\quad(\mathrm{mmHg})\end{array}$ & $56 \pm 32$ & $78 \pm 13$ & * \\
\hline Fasting glucose $(\mathrm{mmol} / \mathrm{l})$ & $4.53 \pm 0.08$ & $4.85 \pm 0.14$ & NS \\
\hline Fasting insulin (mIU/l) & $6.36 \pm 0.3$ & $10.6 \pm 0.97$ & ** \\
\hline HOMA index & $1.29 \pm 0.08$ & $2.27 \pm 0.216$ & ** \\
\hline Total cholesterol $(\mathrm{mmol} / \mathrm{l})$ & $4.64 \pm 0.23$ & $4.48 \pm 0.21$ & NS \\
\hline HDL cholesterol (mmol/l) & $1.59 \pm 0.08$ & $1.13 \pm 0.11$ & \\
\hline LDL cholesterol $(\mathrm{mmol} / \mathrm{l})$ & $2.72 \pm 0.16$ & $3.16 \pm 0.25$ & $\mathrm{~N}$ \\
\hline Triglycerides (mmol/l) & $0.70 \pm 0.08$ & $1.68 \pm 0.20$ & ** \\
\hline Uric acid $(\mu \mathrm{mol} / \mathrm{l})$ & $219.71 \pm 14.2$ & $327.5 \pm 12.9$ & 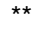 \\
\hline PAl-1 (ng/ml) & $7.4 \pm 2.3$ & $33.9 \pm 5.4$ & ** \\
\hline
\end{tabular}

Statistical analysis was performed using the Mann-Whitney $U$-test. ${ }^{\star} P<0.001 ;{ }^{*} P<0.0001$; NS, not significant.

\section{Statistical analysis}

All data were analyzed using the Statview analysis program. Continuous data are expressed as means \pm S.E.M. Differences between independent variables (lean vs obese) were tested using the Mann-Whitney U-test. Differences between paired variables (SC vs $\mathrm{OM}$ ) were tested using the paired Wilcoxon test. Correlation analysis was performed using the Spearman's test. Significance was defined as a value of $P<0.05$.

\section{Results}

\section{Population baseline characteristics}

Table 1 shows the anthropometric and biochemical characteristics of the subjects. Age, fasting glycemia, total cholesterol and LDL cholesterol were not statistically different between groups. Waist circumference, waist/hip ratio, fat mass, blood pressure, basal insulinemia, HOMA index, circulating levels of triglycerides, uric acid and PAI-1 were higher in obese than in lean subjects, whereas circulating HDL cholesterol concentrations were lower.

Figure 1 Brightfield photomicrographs showing AM immunohistochemistry $(A-E)$ and in situ hybridization $(F-J)$ in various compartments (A, F: blood vessels (lum: lumen; m: media); B, G: stromal cell clusters; $\mathrm{C}, \mathrm{H}$ : isolated stromal cells close to adipocytes) of SC adipose tissue obtained from a lean woman. Sections were counterstained with Mayer's hematoxylin (A-E) or Solid Red (F-J). AM expression (arrows) appears as a brown staining for immunohistochemistry and as silver grains for in situ hybridization. D, I: positive controls: sections were incubated with leptin antibody or with leptin probe respectively. E, J: negative controls: sections were incubated without the AM primary antiserum or with the AM sense probe respectively. Bar equals $20 \mu \mathrm{m}$.

NS

5
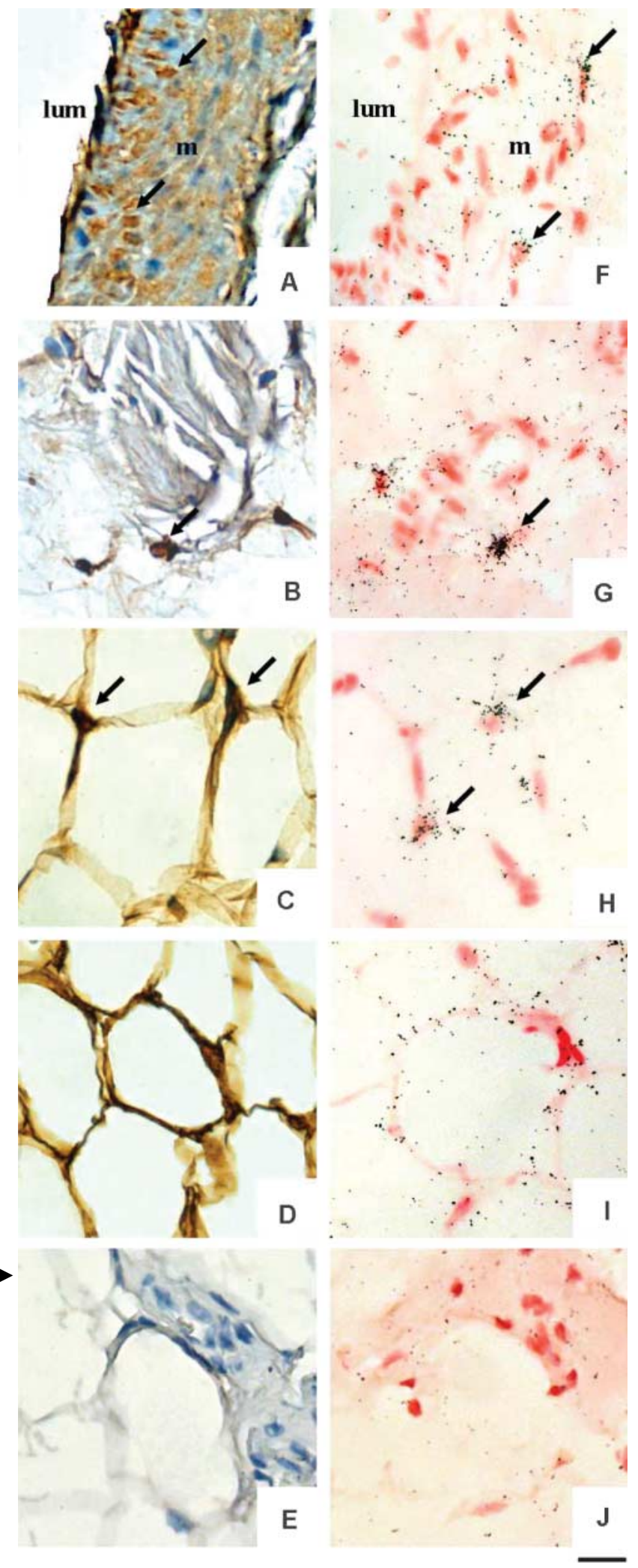


\section{Localization of AM within human adipose tissue}

Analysis of adipose tissue sections showed rare stromal cell clusters corresponding to $18 \% \pm 1.8$ and $16 \% \pm 1.6$ of the studied field in the SC compartment, and to $10 \% \pm 1.5$ and $13 \% \pm 1.9$ of the studied field in the OM compartment, in lean or obese patients, respectively. The remainder of the tissue was composed of adipocytes surrounded by scattered stromal cells.

Figure 1 shows a representative result of AM immunohistochemistry (A-E) and in situ hybridization $(\mathrm{F}-\mathrm{J})$ in SC adipose tissue from a lean woman. Comparable results were obtained with both techniques. A strong staining was found in walls of vessels (Fig. 1A and F), in stromal cell clusters (Fig. 1B and G), and in scattered stromal cells close to adipocytes (Fig. 1C and H). Mature adipocytes were not labeled whereas, when an antibody against leptin (Fig. 1D) or a leptin probe (Fig. 1I) were used, leptin labeling appeared in the cytoplasmic ring of adipocytes. No staining could be detected when the primary AM antiserum was omitted (Fig. 1E) or the AM sense probe was used for in situ hybridization (Fig. 1J), demonstrating the specificity of these procedures.

Localization of AM-IR and AM-mRNA did not differ when techniques were applied to SC tissue obtained from obese subjects and OM tissue from lean and obese subjects (data not shown).

Figure 2 (upper panel) shows a representative result of CRLR, RAMP 2 and RAMP 3 immunohistochemistry in $\mathrm{OM}$ adipose tissue from a lean patient. The three receptors were expressed in vessel walls. Their distribution was comparable in SC tissue from lean patients (not shown). Localization and intensity of the immunocytochemical staining for the above-mentioned receptors were not changed in SC and OM adipose tissue from obese patients (not shown).

\section{AM secretion during in vitro human preadipocytes differentiation}

Since we did not find any AM production by mature adipocytes, we looked at AM secretion during human preadipocytes differentiation. Under our culture conditions, the first mature adipocytes appeared on day 6. Figure 3 shows the results of $\mathrm{AM}$ and leptin secretion from five different SC adipose tissues undergoing in vitro differentiation. AM secretion was high during the first 4 days of culture and decreased steadily thereafter. Leptin secretion followed an opposite pattern with very low levels at the beginning of the study, an increase between days 6 and 8 , and a plateau thereafter.

\section{Semi-quantitative analysis of $A M$ within human adipose tissue}

Because AM-IR was localized both in stromal cell clusters (corresponding to less than 20\% of the

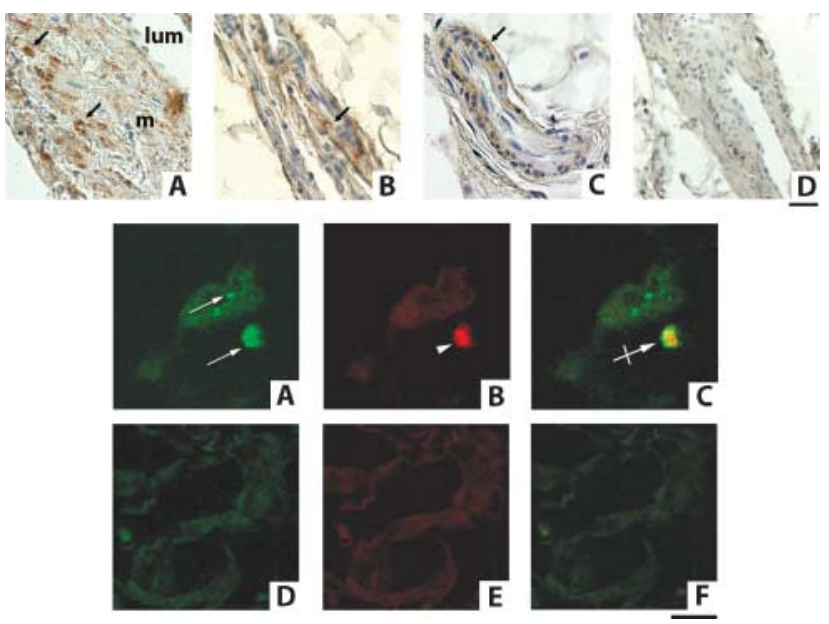

Figure 2 (Upper panels) Brightfield photomicrograph showing CRLR (A), RAMP 2 (B) and RAMP 3 (C) immunohistochemistry in OM adipose tissue obtained from a lean patient. (D) The section was incubated without the primary antiserum. Slides were counterstained with Mayer's hematoxylin. Lum, lumen; $m$, media. Bar equals $20 \mu \mathrm{m}$. (Lower panels) Two-channel confocal scanning of a representative OM adipose tissue section obtained from an obese patient showing immunoreactivities for AM (fluorescein labeling, A, arrows), CD 68 (TRITC labeling, B, arrowhead) and for both $A M$ and $C D 68$ (D, crossed arrow). Corresponding control sections are shown in D-F. Note that AM immunoreactivity was present in blood vessels (green fluorescence) and colocalized with CD 68 (yellow to orange fluorescence) in large cells resembling macrophages. Bar equals $10 \mu \mathrm{m}$.

examined field) and in scattered stromal cells close to adipocytes (corresponding to the major part of the tissue), we maintained this compartment separation for quantification.

In the stromal cell clusters, we found that, in both lean and obese patients, the percentage of labeled

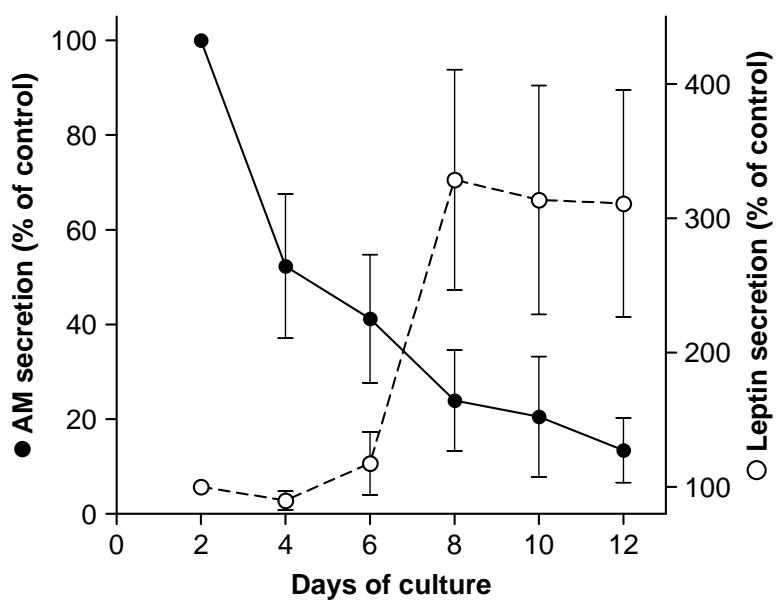

Figure 3 AM (solid circles) and leptin (open circles) secretion from primary cultures of adipose tissue undergoing in vitro differentiation. Adipose tissue stromal cells were prepared and cultured as described in the Subjects and Methods section. Data represent the mean \pm S.E.M. of five primary cultures. 
stromal area was two-fold larger in the OM as compared with the SC compartment (Table 2).

When analysis was focused on stromal tissue close to adipocytes ( $>80 \%$ of examined field), a difference was clearly noticed between lean and obese subjects. Whereas the stained surface (labeled stromal surface/ adipocyte) was 1.7-fold smaller in OM than in SC tissue $(P<0.05)$ in the lean population, this difference disappeared in the obese population. Consequently, the stained surface in the OM compartment was significantly higher in the obese compared with the lean population (Table 2). A similar expression profile was obtained when AM-mRNA was quantified with quantitative RT-PCR (Table 2).

Figure 2 (lower panel) shows a representative result of a double labeling experiment for AM and CD 68 in OM adipose tissue from obese patients. Confocal analysis demonstrated that AM and CD 68 immunoreactivity were colocalized in large cells, resembling macrophages, close to blood vessels.

Quantitative RT-PCR analysis of TNF $\alpha$ mRNA in OM adipose tissue extracts obtained from the entire population studied demonstrated a significant positive correlation with AM mRNA concentrations (Fig. 4).

\section{Correlation between AM adipose tissue levels and metabolic parameters}

In order to assess if tissue AM-IR and AM-mRNA follow the features of the metabolic syndrome, a correlation analysis was performed in the whole population. We found that only OM AM-IR (stained stromal surface divided by the number of adipocytes counted in the examined field) or AM-mRNA was significantly associated with metabolic syndrome parameters. An association was observed between the OM stained area and BMI, waist circumference, systolic blood pressure, HDL cholesterol, HOMA index, PAI-1 levels (Fig. 5) and triglycerides $(r=0.49, P=0.04)$. A positive significant association was also observed between the OM AM-IR in the stromal cell clusters (percentage labeled stromal surface) and triglycerides $(r=0.54, P=0.02)$ or PAI-1 levels $(r=0.49, P=0.04)$.
Correlation analysis also showed a positive relationship between AM-mRNA levels in OM adipose tissue and systolic blood pressure $(r=0.61, P=0.02)$, HOMA index $(r=0.46, P=0.03)$ and triglyceride levels $(r=$ $0.51, P=0.02)$.

No association was noticed when analysis was focused on AM-IR or AM-mRNA in the SC compartment (data not shown).

\section{Discussion}

Our results show that AM is synthesized in SC and OM compartments of human adipose tissue, in agreement with Knerr et al. (15), and that both AM-IR and AMmRNA are located in the stromal compartment of adipose tissue. The stromal fraction of adipose tissue contains tissue matrix, vessels, and various cell populations surrounding adipocytes. We observed that vascular wall cells are a source of AM, as already described $(5,6)$, and contain AM receptors. We performed a partial identification of other stromal cell types involved in AM synthesis. It is known that macrophages, frequently present in adipose tissue (25), produce AM in vitro $(16,26)$. Our results demonstrate that AM and CD 68 proteins were colocalized, strongly suggesting that macrophages within adipose tissue can synthesize AM. A contribution of preadipocytes cannot be excluded. Our observations that the kinetic of AM secretion from preadipocytes undergoing in vitro differentiation was opposite to that of leptin strongly suggest that adipose tissue AM is synthesized by the preadipocyte fraction. The above-mentioned hypothesis is consistent with the findings of Li et al. (12), who demonstrated that AMmRNA was expressed in 3T3-L1 preadipocytes, but was undetectable in adipocytes and that AM-IR was detected in the culture media of 3T3-L1 preadipocytes and adipocytes, with higher concentrations found in preadipocytes. It has recently been reported that in the 3T3-F442A cell line, confluent preadipocytes express high levels of AM-mRNA (14) and that human mesenchymal cell-derived adipocytes in culture

Table 2 Semi-quantitative analysis of AM immunoreactive areas (AM-IR) and AM-mRNA within human adipose tissue. The AM-IR were quantified using the Image software. Eight randomly chosen fields $\left(0.7 \mathrm{~mm}^{2}\right)$ per section were analyzed. For clusters of stroma cells, the stained stromal area was divided by the total surface of the cluster (percentage of labeled stromal area). For stromal tissue close to adipocytes, the stained stromal surface was divided by the number of adipocytes counted in the examined field (labeled stromal surface/adipocyte). AM-mRNA was quantified by quantitative RT-PCR and expressed in arbitrary units (see Subjects and methods section).

\begin{tabular}{lccccc}
\hline & \multicolumn{2}{c}{ Lean population $(n=9)$} & & \multicolumn{2}{c}{ Obese population $(n=13)$} \\
\cline { 2 - 3 } \cline { 5 - 6 } & $\mathrm{SC}$ & $\mathrm{OM}$ & & SC & OM \\
\hline Percentage of labeled stromal area & $0.81 \pm 0.14$ & $1.77 \pm 0.49^{\star}$ & & $0.69 \pm 0.13$ & $1.93 \pm 0.20^{\star}$ \\
Labeled stromal surface/adipocyte & $111 \pm 16$ & $64 \pm 8.5^{*}$ & & $133 \pm 14$ & $103 \pm 8 \S$ \\
AM-mRNA (arbitrary units) & $83.2 \pm 37.7$ & $40.5 \pm 9.9$ & & $76.6 \pm 11$ & $71.9 \pm 13.3 \S$ \\
\hline
\end{tabular}

Comparison between subcutaneous (SC) and omental (OM) adipose tissue was performed using the Wilcoxon matched test, ${ }^{\star} P<0.05$. Comparison between lean and obese populations was performed using the Mann-Whitney $U$-test, $\S P<0.05$. 


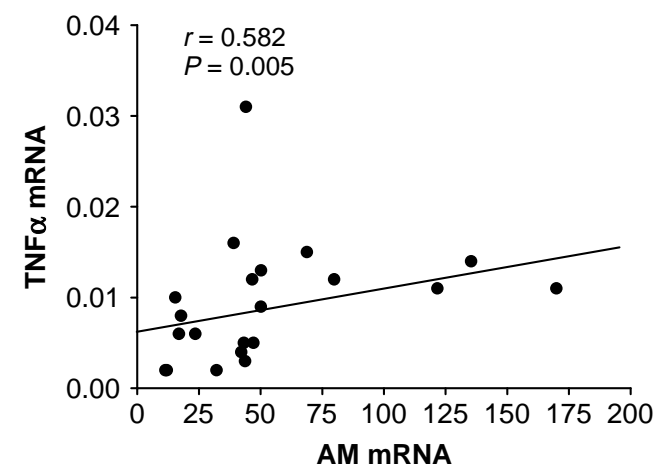

Figure 4 Correlation analysis between AM mRNA and TNF $\alpha$ mRNA measured using quantitative RT-PCR and expressed in arbitrary units (see Subjects and Methods section) in OM adipose tissue extracts obtained from the whole population.

synthetize AM before differentiation when stimulated by proinflammatory cytokines (16). These observations emphasize the importance of the stromal portion of the adipose tissue as a site of adipokine production, as
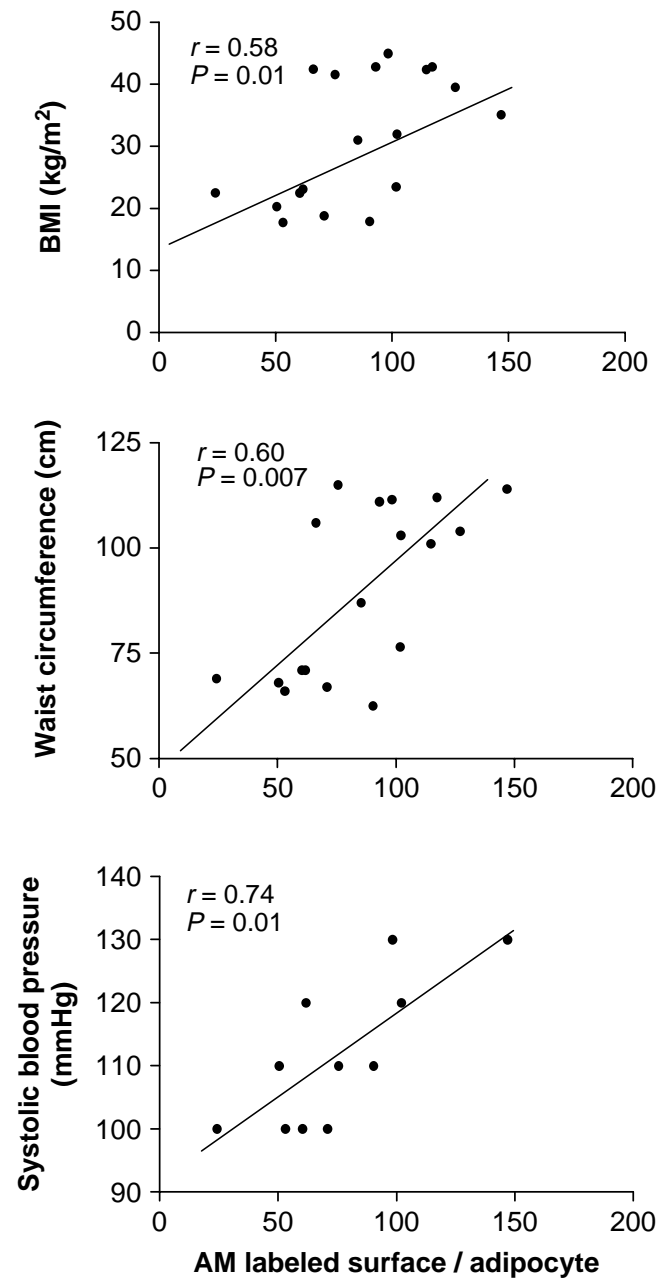

previously reported (27). This hypothesis does not exclude a production of AM by mature adipocytes in a specific environment. Indeed, it has been shown that 3T3-F442A cells (14) as well as differentiated human mesenchymal cells (16) express and secrete AM. However in these studies, cells were cultured with fetal calf serum which provides inflammatory mediators, whereas our culture media were serum-free.

Our data show the presence of large and similar amounts of AM between lean and obese subjects in the SC compartment. Interestingly, compared with lean, obese subjects exhibit higher levels of AM in OM adipose tissue. OM tissue is known to play a major role in obesityrelated illness, and current evidence supports the concept that $\mathrm{OM}$ fat is the main determinant of the metabolic syndrome (28). Park and Lee (29) reported that OM fat reduction in obese patients induces greater beneficial effects on parameters of the metabolic syndrome than SC fat reduction. Recent studies have shown a differential gene expression in the OM adipose tissue of morbidly obese patients, in particular for genes
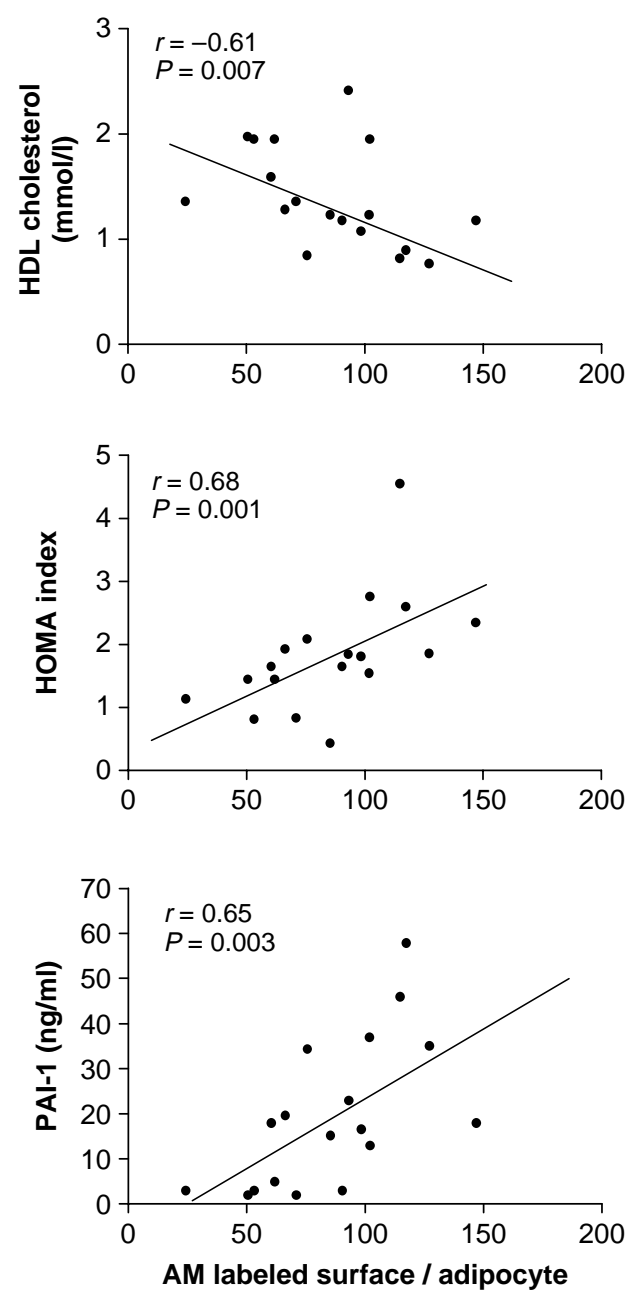

Figure 5 Correlation analysis between AM-IR stromal labeled surface/adipocyte in OM adipose tissue and clinical or biochemical parameters involved in the metabolic syndrome.

www.eje-online.org 
related to lipid and glucose metabolism, compared with lean individuals (30). We found that AM expression in OM tissue correlates with body composition, systolic blood pressure and some biochemical components involved in the metabolic syndrome.

The reason for the increase in OM AM expression during obesity is not clear and the link between AM and the metabolic syndrome deserves to be documented. One can suggest that adipose AM may interplay with the features of the proinflammatory state which is usually present in the metabolic syndrome. Indeed, it was shown that lipopolysaccharide (LPS) stimulates AM mRNA expression in cultured macrophages (31), in undifferentiated human mesenchymal stem cells (16), and in fibroblasts Hs68 (32). Our findings, showing a positive relationship between OM tissue AM-IR and circulating PAI-1 levels and between OM AM and TNF $\alpha$ mRNAs, argue for a connection between AM and inflammation within adipose tissue. In turn, AM increases secretion of macrophage migration inhibitory factor, interleukin 6 and interleukin $1 \beta$ from LPS-stimulated macrophages (31). The abovementioned phenomena can have both morphological and functional consequences. AM can influence adipose tissue development by a stimulatory action on angiogenesis (33), and on preadipocyte multiplication $(32,34)$. Several studies suggest that AM can act on insulin resistance control. It has been shown that AM deficiency induces insulin resistance in mice (35) and that acute hyperinsulinemia increases circulating AM levels in diabetic patients (36) or in uncomplicated obese subjects (37). In obese and/or diabetic patients, AM may, in turn, interact with the regulation of insulinemia (37-40).

In conclusion, our data demonstrate that stromal cells from human adipose tissue, including macrophages, produce AM. Its synthesis increased in the OM territory during obesity and paralleled the features of the metabolic syndrome. Therefore, AM should be considered as a new member of the adipokine family.

\section{Acknowledgements}

We thank Drs C Arniaud, G Bechis and J-P Rosso (Laboratoire de Biochimie et de Biologie Moléculaire, CHU Nord, Marseille) for their help in biochemical measurements. We are indebted to Prof. C Charpin and the technical staff of the anatomopathology laboratory of the CHU Nord for their help in tissue processing.

\section{References}

1 Kitamura K, Kangawa K, Kawamoto M, Ichiki Y, Nakamura S, Matsuo H \& Eto T. Adrenomedullin: a novel hypotensive peptide isolated from human pheochromocytoma. Biochemical and Biophysical Research Communications 1993192 553-560.

2 Eto T. A review of the biological properties and clinical implications of adrenomedullin and proadrenomedullin N-terminal 20 peptide (PAMP), hypotensive and vasodilating peptides. Peptides 200122 1693-1711.
3 Hay DL \& Smith DM. Adrenomedullin receptors: molecular identity and function. Peptides 200122 1753-1763.

4 Nishikimi T, Horio T, Sasaki T, Yoshihara F, Takishita S, Miyata A, Matsuo H \& Kangawa K. Cardiac production and secretion of adrenomedullin are increased in heart failure. Hypertension 1997 30 1369-1375.

5 Sugo S, Minamino T, Kangawa K, Miyamoyo K, Kitamura K, Sakata J, Eto T \& Matsuo H. Endothelial cells actively synthesize and secrete adrenomedullin. Biochemical and Biophysical Research Communications 1994201 1160-1166.

6 Sugo S, Minamino N, Shoji H, Kangawa K, Kitamura K, Eto T \& Matsuo $\mathrm{H}$. Production and secretion of adrenomedullin from vascular smooth muscle cells: augmented production by tumor necrosis factor-alpha. Biochemical and Biophysical Research Communications 1994203 719-726.

7 Nishikimi T, Kitamura K, Saito Y, Shimada K, Ishimitsu T, Takamiya M, Kangawa W, Matsuo H, Eto T, Omae T \& Matsuoka $\mathrm{H}$. Clinical studies on the site of production and clearance of circulating adrenomedullin in human subjects. Hypertension 1994 24 600-604.

8 Nishikimi T \& Matsuoka H. Cardiac adrenomedullin: its role in cardiac hypertrophy and heart failure. Current Medicinal Chemistry, Cardiovascular and Hematological Agents 20053 231-242.

9 Kuroki M, Nakamura S, Kitamura K, Hisanaga S, Fujimoto S \& Eto T. Plasma adrenomedullin levels in patients with diabetes. Diabetes Care $200023253-254$.

10 Kato J, Kitamura K, Uemura T, Kuwasako K, Kita T, Kangawa K \& Eto T. Plasma levels of adenomedullin and atrial and brain natriuretic peptides in the general population: their relations to age and pulse pressure. Hypertension Research 200225 887-889.

11 Minami J, Nishikimi T, Ishimitsu T, Makino Y, Kawano Y, Takishita S, Kangawa $\mathrm{K}$ \& Matsuoka $\mathrm{H}$. Effect of a hypocaloric diet on adrenomedullin and natriuretic peptides in obese patients with essential hypertension. Journal of Cardiovascular Pharmacology 2000 36 S83-S86.

12 Li Y, Totsune K, Takeda K, Furuyama K, Shibahara S \& Takahashi K. Decreased expression of adrenomedullin during adipocyte-differentiation of 3T3-L1 cells. Hypertension Research 200326 S41-S44.

13 Fukai N, Yoshimoto T, Sugiyama T, Ozawa N, Sato R, Shichiri M \& Hirata Y. Concomitant expression of adrenomedullin and its receptor components in rat adipose tissues. American Journal of Physiology, Endocrinology and Metabolism 2005288 E56-E62.

14 Harmancey R, Senard JM, Pathak A, Desmoulin F, Claparols C, Rouet $\mathrm{P} \&$ Smih $\mathrm{F}$. The vasoactive peptide adrenomedullin is secreted by adipocytes and inhibits lipolysis through NO-mediated beta-adrenergic agonist oxidation. FASEB Journal 200519 10451047.

15 Knerr I, Schirl C, Horbach T, Stuppy A, Carbon R, Rascher W \& Dotsch J. Maturation of the expression of adrenomedullin, endothelin-1 and nitric oxide synthases in adipose tissues from childhood to adulthood. International Journal of Obesity and Related Metabolic Disorders 200529 275-280.

16 Linscheid P, Seboek D, Zulewski H, Keller U \& Muller B. Autocrine/paracrine role of inflammation-mediated calcitonin gene-related peptide and adrenomedullin expression in human adipose tissue. Endocrinology 2005146 2699-2708.

17 Matthews DR, Hosker JP, Rudenski AS, Naylor BA, Treacher DF \& Turner RC. Homeostasis model assessment: insulin resistance and beta-cell function from fasting plasma glucose and insulin concentrations in man. Diabetologia 198528 412-419.

18 Declerck PJ, Alessi MC, Verstreken M, Kruithof EK, Juhan-Vague I \& Collen D. Measurement of plasminogen activator inhibitor 1 in biologic fluids with a murine monoclonal antibody-based enzymelinked immunosorbent assay. Blood 199871 220-225.

19 Ouafik L'H, Sauze S, Boudouresque F, Chinot O, Delfino C, Fina F, Vuaroqueaux V, Dussert C, Palmari J, Dufour H, Grisoli F, Casellas P, Brünner N \& Martin PM. Neutralization of adrenomedullin inhibits the growth of human glioblastoma cell lines in vitro and suppresses tumor xenograft growth in vivo. American Journal of Pathology $20021601279-1292$. 
20 Fernandez-Sauze S, Delfino C, Mabrouk K, Dussert C, Chinot O, Martin PM, Grisoli F, Ouafik L \& Boudouresque F. Effects of adrenomedullin on endothelial cells of the multistep process of angiogenesis: involvement of CRLR/RAMP2 and CRLR/RAMP3 receptors. International Journal of Cancer 2004108 797-804.

21 Rasband WS \& Bright DS. NIH Image: a public domain image processing program for the Macintosch. Microbeam Analysis 1995 4 137-149.

22 Bastelica D, Morange P, Berthet B, Borghi H, Lacroix O, Grino M, Juhan-Vague I \& Alessi MC. Stromal cells are the main plasminogen activator inhibitor-1-producing cells in human fat. Evidences of differences between visceral and subcutaneous deposits. Arteriosclerosis, Thrombosis, and Vascular Biology 2002 22 173-178.

23 Grino M \& Zamora AJ. An in situ hybridization histochemistry technique allowing simultaneous visualization by the use of confocal microscopy of three cellular mRNA species within individual neurons. Journal of Histochemistry and Cytochemistry $199846753-759$.

24 Kitamura K, Sakata J, Kangawa K, Kojima M, Matsuo H \& Eto T. Cloning and characterization of cDNA encoding a precursor for adrenomedullin. Biochemical and Biophysical Research Communications $1993194720-725$.

25 Di Gregorio GB, Yao-Borengasser A, Rasouli N, Varma V, Lu T, Miles LM, Ranganathan G, Peterson CA, McGehee RE \& Kern PA. Expression of CD68 and macrophage chemoattractant protein-1 genes in human adipose and muscle tissues: association with cytokine expression, insulin resistance, and reduction by pioglitazone. Diabetes $2005 \mathbf{5 4} 2305-2313$.

26 Kubo A, Minamino N, Isumi Y, Kangawa K, Dohi K \& Matsuo H. Adrenomedullin production is correlated with differentiation in human leukemia cell lines and peripheral blood monocytes. FEBS Letters $1998 \mathbf{4 2 6} 233-237$.

27 Fain JN, Madan AK, Hiler ML, Cheema P \& Bahouth SW. Comparison of the release of adipokines by adipose tissue, adipose tissue matrix, and adipocytes from visceral and subcutaneous abdominal adipose tissues of obese humans. Endocrinology 2004 $1452273-2282$.

28 Carr DB, Utzschneider KM, Hull RL, Kodama K, Retzlaff BM, Brunzell JD, Shofer JB, Fish BE, Knopp RH \& Kahn SE. Intraabdominal fat is a major determinant of the National Cholesterol Education Program Adult Treatment Panel III criteria for the metabolic syndrome. Diabetes 200453 2087-2094.

29 Park HS \& Lee K. Greater beneficial effects of visceral fat reduction compared with subcutaneous fat reduction on parameters of the metabolic syndrome: a study of weight reduction programmes in subjects with visceral and subcutaneous obesity. Diabetic Medicine 200522 266-272.

30 Baranova A, Collantes R, Gowder SJ, Elariny H, Schlauch K, Younoszai A, King S, Randhawa M, Pusulury S, Alsheddi T, Ong JP,
Martin LM, Chandhoke V \& Younossi ZM. Obesity-related differential gene expression in the visceral adipose tissue. Obesity Surgery 200515 758-765.

31 Wong LY, Cheung BM, Li YY \& Tang F. Adrenomedullin is both proinflammatory and antiinflammatory: its effects on gene expression and secretion of cytokines and macrophage migration inhibitory factor in NR8383 macrophage cell line. Endocrinology $20051461321-1327$.

32 Isumi Y, Minamino N, Katafuchi T, Yoshioka M, Tsuji T, Kangawa $\mathrm{K}$ \& Matsuo H. Adrenomedullin production in fibroblasts: its possible function as a growth regulator of Swiss 3T3 cells. Endocrinology $19981392552-2563$.

33 Nagaya N, Mori H, Murakami S, Kangawa K \& Kitamura S. Adrenomedullin: angiogenesis and gene therapy. Review: American Journal of Physiology, Regulatory, Integrative and Comparative Physiology 2005288 R1432-R1437.

34 Withers DJ, Coppock HA, Seufferlein T, Smith DM, Bloom SR \& Rozengurt E. Adrenomedullin stimulates DNA synthesis and cell proliferation via elevation of cAMP in Swiss 3T3 cells. FEBS Letters 1996378 83-87.

35 Shimosawa T, Ogihara T, Matsui H, Asano T, Ando K \& Fujita T. Deficiency of adrenomedullin induces insulin resistance by increasing oxidative stress. Hypertension 200341 1080-1085.

36 Katsuki A, Sumida Y, Gabazza EC, Murashima S, Urakawa H, Morioka K, Kitagawa N, Tanaka T, Araki-Sasaki R, Hori Y, Nakatani K, Yano Y \& Adachi Y. Acute hyperinsulinemia is associated with increased circulating levels of adrenomedullin in patients with type 2 diabetes mellitus. European Journal of Endocrinology 2002147 71-75.

37 Letizia C, Iacobellis G, Caliumi C, Leonetti F, Cotesta D, Ribaudo MC, Petramala L, Cianci R, Celi M, D’Erasmo E \& Di Mario U. Acute hyperinsulinemia is associated with increased plasma adrenomedullin concentrations in uncomplicated obesity. Experimental and Clinical Endocrinology and Diabetes 2005113 171-175.

38 Najib S \& Sanchez-Margalet V. Homocysteine thiolactone inhibits insulin signaling, and glutathione has a protective effect. Journal of Molecular Endocrinology 200127 87-91.

39 Rudich A, Tisrosch A, Potashnik R, Hemi R, Kanety H \& Bashan N. Prolonged oxidative stress impairs insulin-induced GLUT4 translocation in 3T3-L1 adipocytes. Diabetes $1998 \mathbf{4 7} 1562-1569$.

40 Bertelsen M, Anggard EE \& Carrier MJ. Oxidative stress impairs insulin internalization in endothelial cells in vitro. Diabetologia 200144 605-613.

Received 25 November 2005

Accepted 29 March 2006 